\title{
Paleogeography and biostratigraphy of the Austral basin in Argentina and Chile: An appeal for sound systematics
}

The Austral basin of Patagonia in southern South America contains one of the most complete Cretaceous sedimentary sections in the world. Many years of study have determined the biostratigraphic history of the Lower Cretaceous marine sediments, which have been divided into 10 assemblage zones. Lithological differences and numerous ammonoid fossil assemblages from two groups of sections in the northern part of the basin provide a history of the evolution of these Lower Cretaceous sedimentary sections.

During Hauterivian time, the transgressive sea had its maximum advance, and thick sequences of black shales accumulated in pelagic environments under euxinic conditions. The fossil fauna was of very low diversity and had a distinctively endemic character. In the Barremian, a regressive cycle began that was characterized by maximum progradation of littoral facies and very low faunal diversity. This changed in the late Barremian when the faunal assemblage was linked to coeval South African faunas through free marine connections between southern Patagonia and southeastern Africa. The Aptian recorded the highest faunal diversity as a result of the open circulation of the South Atlantic Ocean. This was followed by abrupt faunal changes at the beginning of the Albian, when the basinal facies were limited to a small part of the central Austral basin. The fossil fauna first became more cosmopolitan, and then the sediments became poorly fossiliferous. (Ed.)

\section{Introduction}

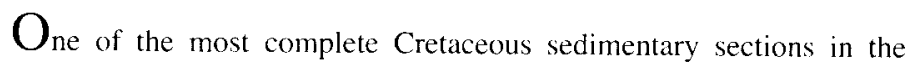
world has been, for many years, in a state of uncertainty regarding stratigraphy, paleogeography, and faunal successions. This is the marine section that crops out in the Patagonian cordillera region of southern South America. Here, endless controversy and discussions have centered around the evolution of the basin and have included uncertainties of hiatuses, regional unconformities, faunal breaks, and endemism. These uncertainties have affected not only the biostratigraphy of the basin, but they also have produced many problems in the analysis of depositional cycles and sequence stratigraphy. In addition. the lack of a systematic approach in studying the abundant ammonoid faunas has hindered efforts to study the ways in which the evolving faunas have adjusted to the transient environments.

This situation is, obviously, not limited to the Austral basin of Patagonia, but it is more widespread than is generally known. As an example, we can examine the problem of the Hauterivian-Barremian boundary in the Mediterranean region. In 1840, the famous naturalist Alcide d'Orbigny described the species Ammonites angulicostatus that came from the Neocomian deposits of Chamateuil, Castellane, France. He gave a complete and beautiful, although most probably imprecise. reconstruction of the fossil. Ever since that time, a perpetual argument has continued about its age and stratigraphic position, an argument that has not finished yet. The main problem is to establish how many horizons contain Pseudothurmannia, and if more than one horizon is proved, the next problem is to establish how many of them correspond to the index species $P$. angulicostata. In addition, the poor preservation of the d'Orbigny specimens that definitely did not correspond to the published fossil reconstruction induced authors such as Kilian (1888) to refer specimens to the species $P$. angulicostata, even though they belonged to a different genus and had a different stratigraphic position.

Although the argument continues, the Pseudothurmannia beds seem to characterize a thin horizon in which Pseudothurmannia apparently is limited. Unfortunately, they are placed variously in the Hauterivian or Barremian because of the fact that a global scheme does not exist for the Hauterivian-Barremian boundary in the Mediterranean area (Lapeyre and Thomel, 1974; see also Durshchits, 1962; Rawson, 1983; Birkelund and others, 1984).

Similar problems have been solved in Patagonia as the result of many years of field work and systematic fossil collection, fine stratigraphic and sedimentological studies, and sound taxonomic analyses of the ammonoid faunas.

\section{The case of Sanmartinoceras patagonicum}

A historic case of biostratigraphic uncertainty is the study of an ammonite species in Patagonia. Bonarelli and Nágera (1921), who did pioneer work on the stratigraphy of the Mesozoic of the Austral basin, described many invertebrate fossils, among them a new genus and species of an aconeceratid ammonite: Sanmartinoceras patagonicum. Since then, several authors have placed other specimens from different localities in Patagonia (and Antarctica) in the same species, regardless of their stratigraphic position and morphological differences (see fig. 1). In a more worldwide context. some later authors restricted the genus Sammartinoceras to the late Aptian. while others extended its 


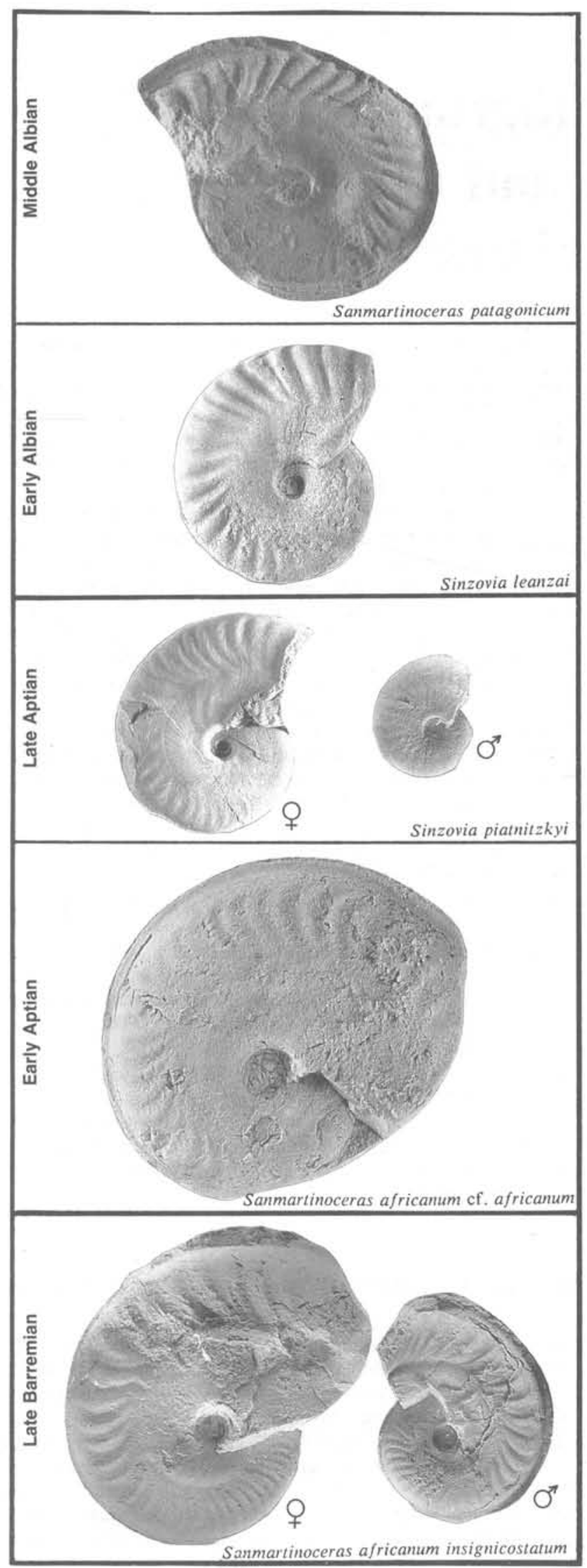

biochron up to the early Albian. The confusion that existed in the early 1970 s prompted Thomson (1974, p. 43) to write an extensive account of the age significance of the genus Sanmartinoceras. In figure 1, we can observe species having a superficially similar morphology that were all assigned to $S$. patagonicum, which extended the range of the species from the late Barremian to the late Albian or earliest Cenomanian, if one accepts the original age of the species as proposed by Bonarelli and Nágera (1921, p. 28).

Riccardi and others (1987) wrote a monographic paper that dealt with the aconeceratid ammonites. They solved the case of Sanmartinoceras patagonicum, as shown in figure 1 where a series of species are arranged stratigraphically and some show dimorphic pairs. They also answered a series of taxonomic and stratigraphic problems on a worldwide scale. However, a similar problem exists for the same species group in Antarctica, where the problem still is unresolved mainly because of the difficulty in establishing a precise stratigraphy.

The preceding examples are given in order to show the problems. Now, I would like to present some answers. As an example, I am going to discuss the evolution of the Lower Cretaceous sedimentary sections of the Austral basin, as seen from a biostratigraphic point of view.

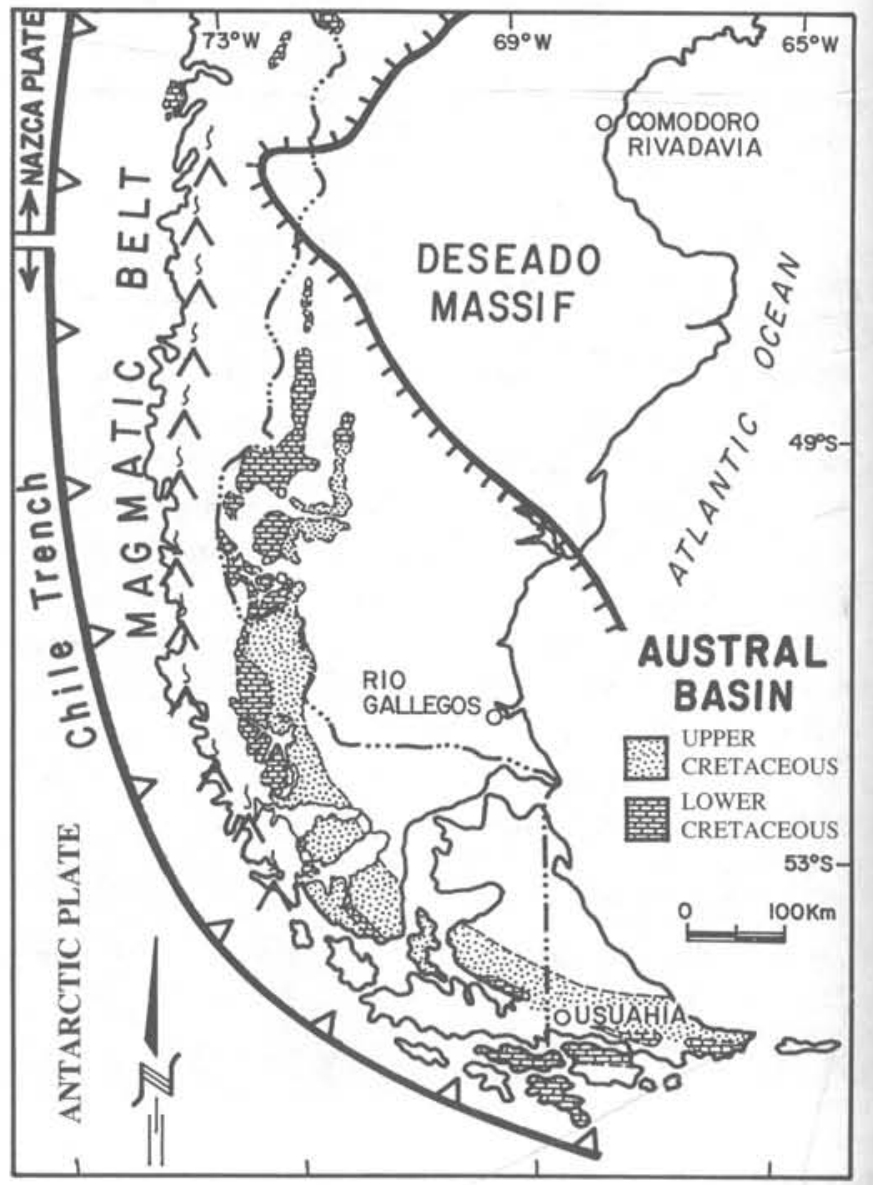

Figure 2.-The Austral basin of Argentina and Chile. The basin is located in the southern tip of the South American plate, which converges with the Nazca and Antarctic plates north of the basin.

Figure 1.-Different genera and species that have been all grouped in Sanmartinoceras patagonicum, arranged according to their age. Note also the dimorphic pairs. 


\section{The Austral basin}

The Austral (or Magallanes) basin is located in the southern tip of the South American plate along its convergent boundary with the oceanic part of the Antarctic plate. North of the basin is the Aysén triple junction of the Nazca, South American, and Antarctic plates (fig. 2).

The Austral basin is a typical backarc basin developed at the time of the opening of the South Atlantic Ocean in Middle and Late Jurassic time. The sedimentary sequence accounts for more than $8 \mathrm{~km}$ of sediments that range in age from the Late Jurassic to the Cenozoic (Russo and Flores, 1972).

The basin extends from latitude $46^{\circ}$ to $55^{\circ} \mathrm{S}$., and it has two distinctive elements. Toward the east is an extensive clastic platform that is known as the Springhill platform, which is covered by a thick blanket of Cenozoic deposits (for details, see Riccardi and Rolleri, 1980). This is a horizontally lying wedge of Lower Cretaceous sequences, known exclusively through intensive oil-exploration drilling. In the northern part of the basin, the eastern foreland edge is controlled by the outline of the Deseado Massif (fig. 2). This massif is a large block of Late Proterozoic to Early Cambrian low-grade metamorphic rocks that have with a passive cover of upper Paleozoic to lower Mesozoic deposits. This block was stable and rigid during Mesozoic and Cenozoic times, and its behavior was linked closely with the evolution of the passive margin during the opening of the South Atlantic Ocean. In contrast, the western part of the basin comprises a fold and thrust belt (Ramos, 1989) that controls the excellent exposures along the foothills of the Patagonian cordillera. The western border of the basin coincides with the Patagonian batholith, a composite multiepisodic batholith that has registered the complex subduction history of the magmatic belt since late Paleozoic times (Ramos, 1983).

\section{Cretaceous localities and faunal zonation}

The Cretaceous sediments crop out in a narrow but complex band that extends through the northern part of the Austral basin in a north-south trend along the eastern foothills of the cordillera, whereas toward the south, these sediments expand to the east (Macellari, 1988) (see fig. 3 ). The relevant localities are shown in figure 3 , as they have provided most of the critical fossils that have been used for establishing the local zonation.

The Lower Cretaceous sediments of the Austral basin have been divided into 10 assemblage zones and two faunules, and they have been correlated tentatively with the European standard zones (Riccardi, $1984 a, b ; 1988$ ). In figure 4 , I show the local assemblage zones for the Hauterivian to the middle Albian, as well as their faunal ammonoid components for selected localities discussed below as examples of the biostratigraphic analyses of Lower Cretaceous sequences in the Austral basin.

\section{Río Belgrano-Río Roble-Chorrillo del Medio-Tucu Tucu-Arroyo La Potranquita stratigraphic sections}

Two groups of sections in the northern part of the Austral basin are analyzed in order to see the biostratigraphic variations that are parallel to and perpendicular to the axis of the basin. The first section cuts the basin from north to south, and the second section cuts it from east to west.

A series of key sections is exposed along the foothills of the region from Río Belgrano to Arroya La Potranquita (figs. 3, 5), and Lower Cretaceous deposits are found here as different facies. The base of the stratigraphic sequence is exposed only in the Río Belgrano locality, where coarse quartzitic sandstones range from a continental fluvial facies to a marine littoral facies. A thick blanket of black shales

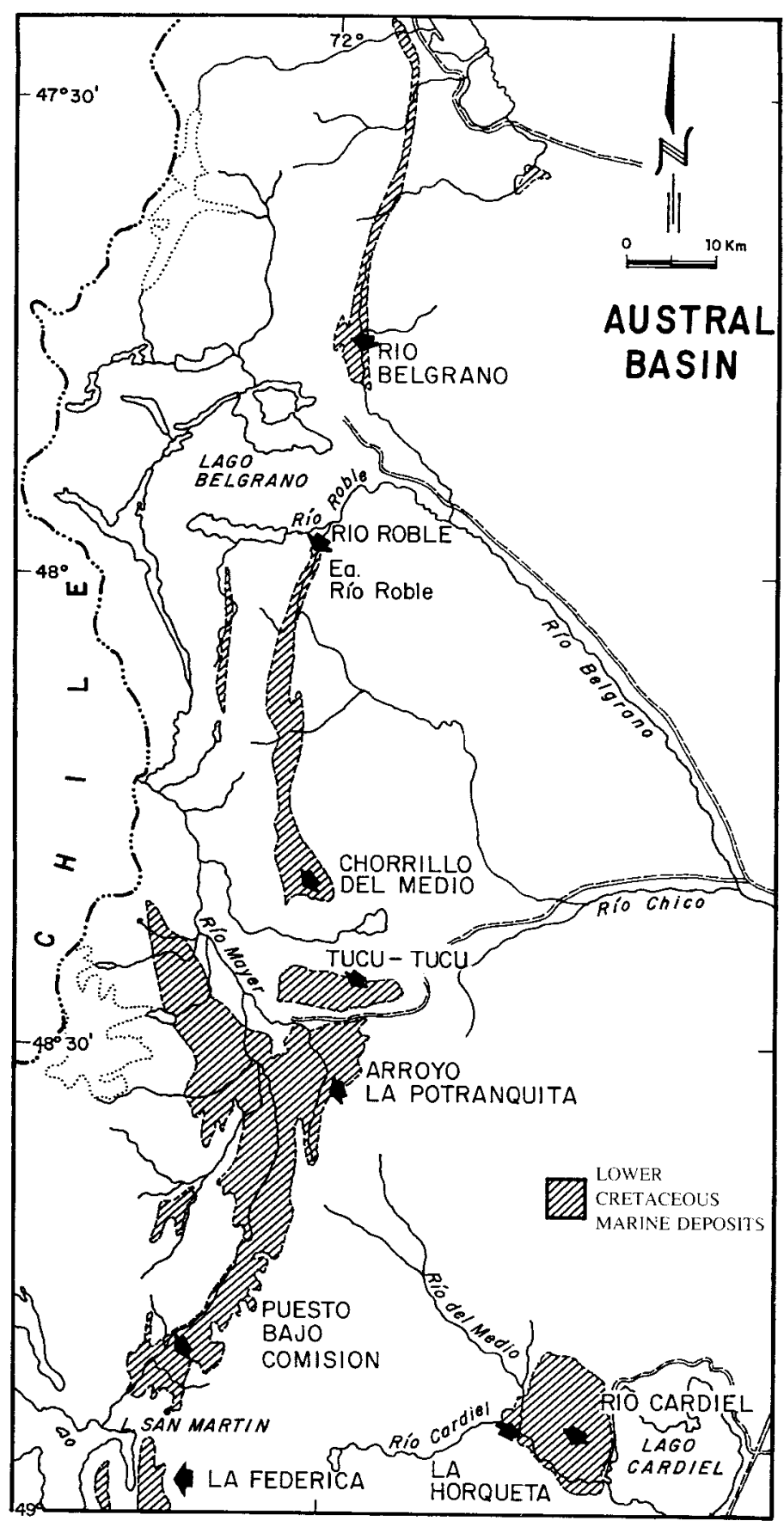

Figure 3.-Lower Cretaceous marine deposits of the Austral basin and the most relevant fossil localities mentioned in the text.

of a basinal facies is distributed widely through all the area and bears several fossil horizons, as seen in the Rio Roble section (fig. 6). Covering this shale is a prograding sequence of green sandstones and black shales that also includes horizons containing abundant fossils. From a lithological point of view, the region is quite monotonous, but when a systematic biostratigraphy is done. five different levels of assemblage zones are seen clearly.

In the northern part of this north-south section, abundant ammonoids from levels I and II (figs. 4, 5) are preserved in black shales. and fossils from levels III and younger are preserved in the littoral 


\begin{tabular}{|c|c|c|c|c|c|c|c|c|c|c|c|c|}
\hline \multicolumn{2}{|c|}{ AGE } & ASSEMBLAGE ZONE & FAUNAL COMPONENTS & 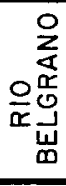 & 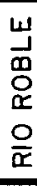 & 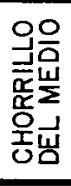 & 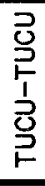 & 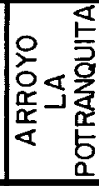 & 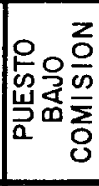 & 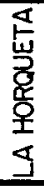 & 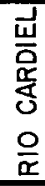 & 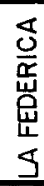 \\
\hline \multirow{2}{*}{$\frac{z}{\frac{z}{m}}$} & $\frac{\Phi}{\frac{D}{z}}$ & $\begin{array}{l}\text { VIII- Sanmartinoceras } \\
\text { patagonicum } \\
\text { Assemblage Zone }\end{array}$ & $\begin{array}{l}\text { Sanmartinoceras patagonicum } \\
\text { "Feruglioceras platnitzkyi" }\end{array}$ & & & & & & & & & \\
\hline & 产 & $\begin{array}{l}\text { VII-Aioloceras } \\
\text { argentinum } \\
\text { Assemblage Zone }\end{array}$ & $\begin{array}{l}\text { Aioloceras argentinum } \\
\text { Sinzovia leanzai } \\
\text { Rossalites imlayi } \\
\text { Beudanticeras rollerii } \\
\text { Cleoniceras santacrucense }\end{array}$ & & & & & & & & & \\
\hline \multirow{2}{*}{$\begin{array}{l}z \\
\frac{a}{b} \\
a \\
a\end{array}$} & $\begin{array}{l}\text { 음 } \\
\text { 음 }\end{array}$ & $\begin{array}{l}\text { VI- Peltocrioceras } \\
\text { deeckei } \\
\text { Assemblage Zone }\end{array}$ & $\begin{array}{l}\text { Peltocrioceras deeckei } \\
\text { Helicancylus patagonicum } \\
\text { Lithancylus guanacoense } \\
\text { Sanmartinoceras cardielense } \\
\text { Sinzovia piatnitzkyi } \\
\text { Ptychoceras sp. } \\
\text { Feruglioceras piatnitzkyi }\end{array}$ & & & & & & & & & \\
\hline & 高 & $\begin{array}{c}V \text { - Australiceras } \\
\text { - Tropaeum } \\
\text { Assemblage Zone }\end{array}$ & $\begin{array}{l}\text { Australiceras cardielense } \\
\text { Tropaeum (Tropaeum ) sp. } \\
\text { Tropaeum (Tropaeum) inflatum } \\
\text { Tropaeum (Australotropaeum) magnum } \\
\text { Sanmartinoceras walshense } \\
\text { Sanmartinoceras africanum af africa- } \\
\text { Toxoceratoides nagerai } \\
\text { Helicancylus bonarellii }\end{array}$ & & & & & & & & & \\
\hline \multirow{2}{*}{ 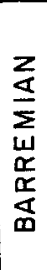 } & $\begin{array}{l}\text { 高 } \\
\stackrel{2}{\frac{2}{3}}\end{array}$ & $\begin{array}{c}\text { IV-Colchidites vula- } \\
\text { nensis australis } \\
\text { Assemblage Zone }\end{array}$ & $\begin{array}{l}\text { Colchidites vulanensis australis } \\
\text { Heteroceros elegans } \\
\text { Sanmartinoceras africanum } \\
\text { insignicostatum }\end{array}$ & & & & & & & & & \\
\hline & 吕 & \begin{tabular}{|} 
/II-Hatchericeras \\
patagonense \\
Assemblage Zone
\end{tabular} & $\begin{array}{l}\text { Hatchericeras patagonense } \\
\text { Hatchericeras semilaeve } \\
\text { Cryptocrioceras yrigoyeni } \\
\text { Hemihoplites varicostatus }\end{array}$ & & & & & & & & & \\
\hline \multirow{2}{*}{$\begin{array}{l}\frac{z}{a} \\
\geq \\
\frac{a}{\alpha} \\
w \\
\frac{5}{2} \\
\frac{a}{1}\end{array}$} & 产 & $\begin{array}{l}\text { //-Favre//a wilckensi } \\
\text { Assemblage Zone }\end{array}$ & $\begin{array}{l}\text { Favrella wilckensi } \\
\text { Protaconeceras patagoniense } \\
\text { Hemihoplites varicostatus }\end{array}$ & & & & & & & & & \\
\hline & 产 & $\begin{array}{l}\text { /-Favre//a amerícana } \\
\text { Assemblage Zone }\end{array}$ & $\begin{array}{l}\text { Favrella americana } \\
\text { Hemihoplites ploszkiewiczi } \\
\text { Aegocrioceras sp. }\end{array}$ & & & & & & & & & \\
\hline
\end{tabular}

Figure 4. - Lower Cretaceous local assemblage zones and their faunal components from different localities of the Austral basin.

sandstones. Ammonites from the same levels (III and IV) are found in black shales in the southern sections as well. Based on these lithological differences and the numerous fossil assemblages, a precise reconstruction of the basin can be done along the Hauterivian-Barremian boundary. This reconstruction is illustrated in the biostratigraphic panel of figure 7 , where the different fossil control points outline the migration of the various lithologic units in relation to time.

Puesto Bajo Comisión-La Horqueta-Río Cardiel-La Federica stratigraphic sections

A similar analysis can be done for the Aptian-Albian transition. The thick and rapid progradation of the sea during early Albian time deposited littoral continental and marine sandstones almost directly above the marine black shales in the Puesto Bajo Comisión section, while the sea was still dominant further south in La Federica area (figs. 3. 8). This reconstruction is based on ammonoid fossils from levels $V$, VI, and VII, as detailed in figure 4 . The reconstruction illustrates the rapid changes among basinal, marine littoral, continental littoral, and fluvial facies that took place within a few kilometers of distance (fig. 9). Once again, only through a systematic study of the abundant ammonite fauna is it possible to recognize the extent and vertical limits of the different fossil assemblages.

These two groups of sections are just a few of the many exampies that show us the need for combining precise ammonoid systematics and field stratigraphic studies. Together these studies allow us to reconstruct the history of the basin at different times.

\section{Paleobiogeographic history}

Based on the type of information described, the paleobiogeographic history of the Lower Cretaceous deposits of the Austral basin can be discussed in detail since the Hauterivian. However, biostratigraphic control of the earlier Berriasian to Valanginian interval is still inadequate, mainly owing to the lack of good outcrops and the poor preser- 


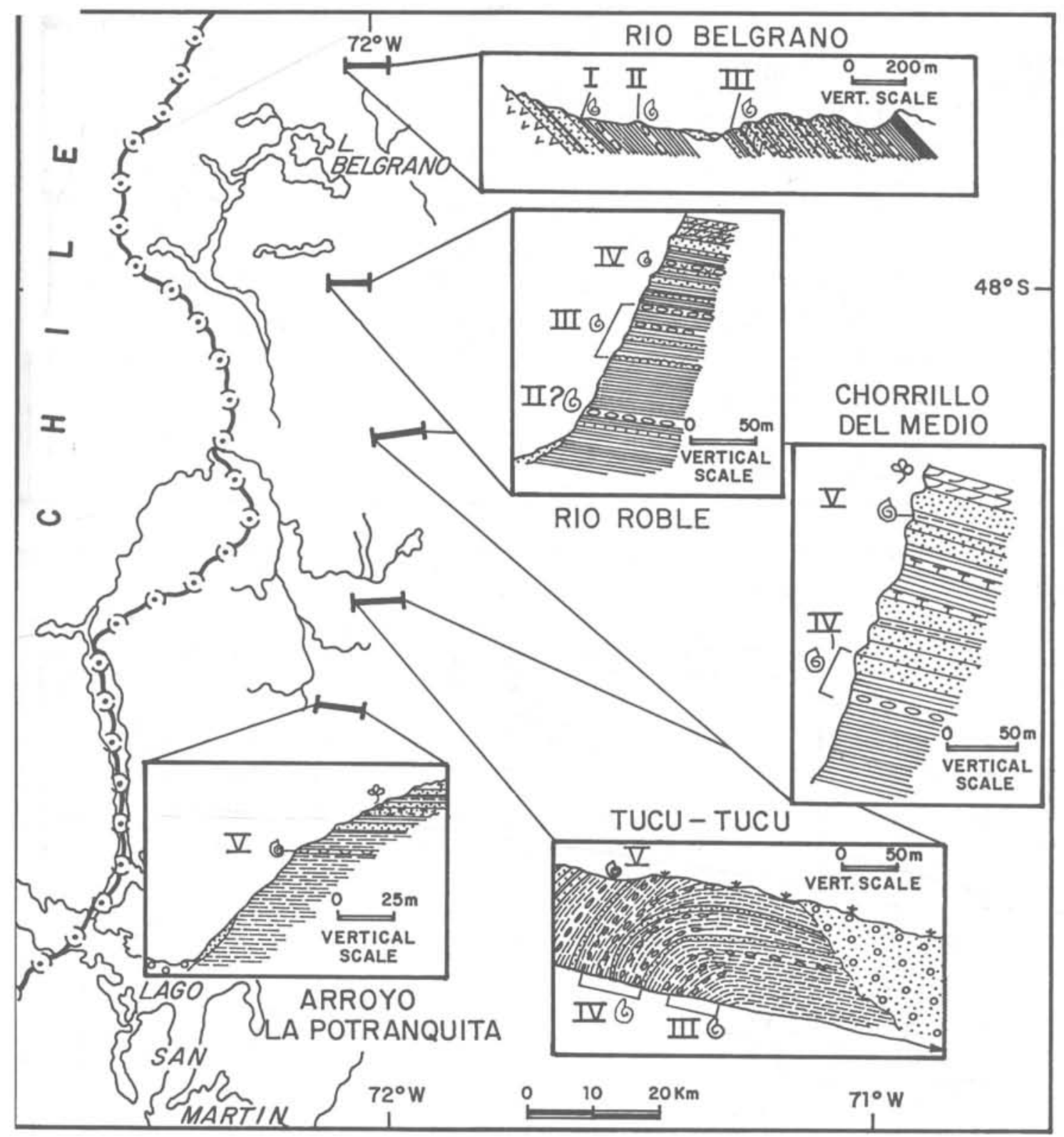

Figure 5.-Northern part of the Austral basin showing the pertinent stratigraphic sequences. Roman numerals on each section indicate the corresponding ammonoid assemblage zones as shown in figures 4 and 7.

Figure 6.-General view of the Rio Roble locality. Black shales (dark tones) and green sandstones (white tones) bearing assemblage zone levels II?, III, and IV are exposed in a 200m-thick section. 
Figure 7.-Biostratigraphic panel showing the corresponding age, assemblage zone, and relation of facies of the Lower Cretaceous sediments from different localities in the northern part of the Austral basin. These localities parallel the axis of the basin.

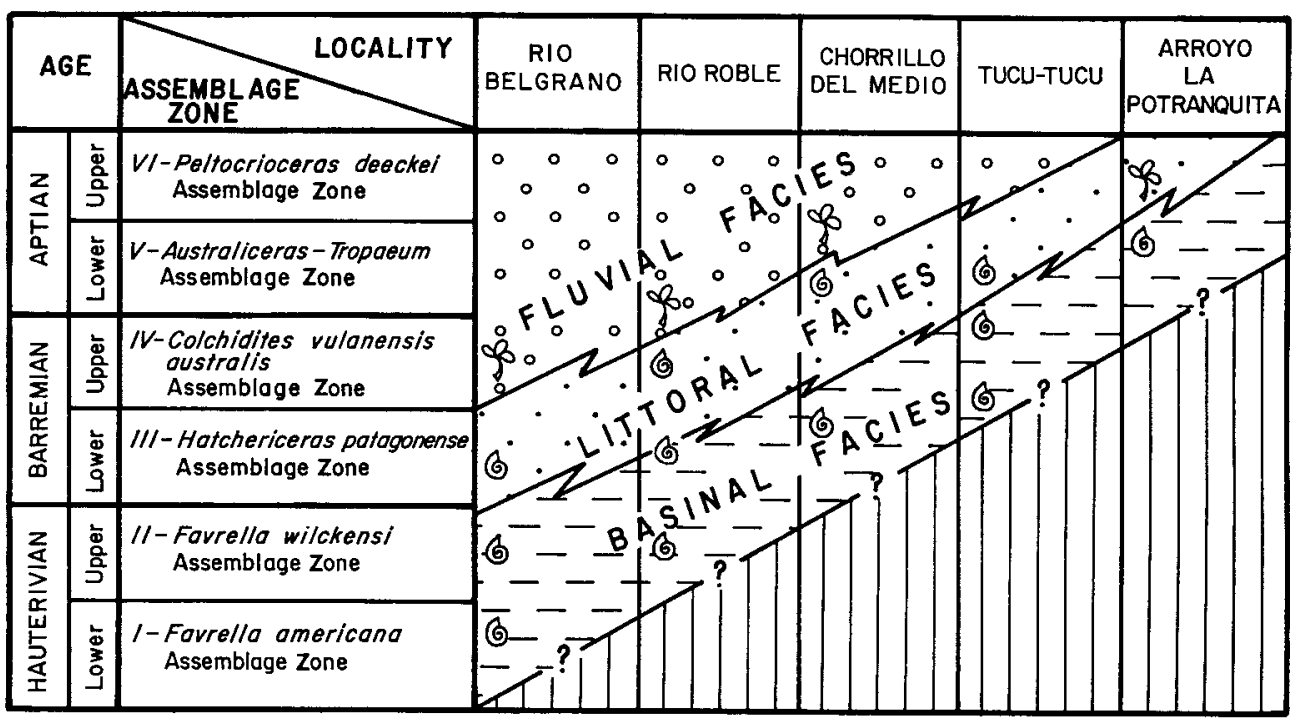

Figure 8.-West-central part of the Austral basin showing the pertinent stratigraphic sequences. Roman numerals on each section indicate the corresponding ammonoid assemblage zones as shown in figures 4 and 9.

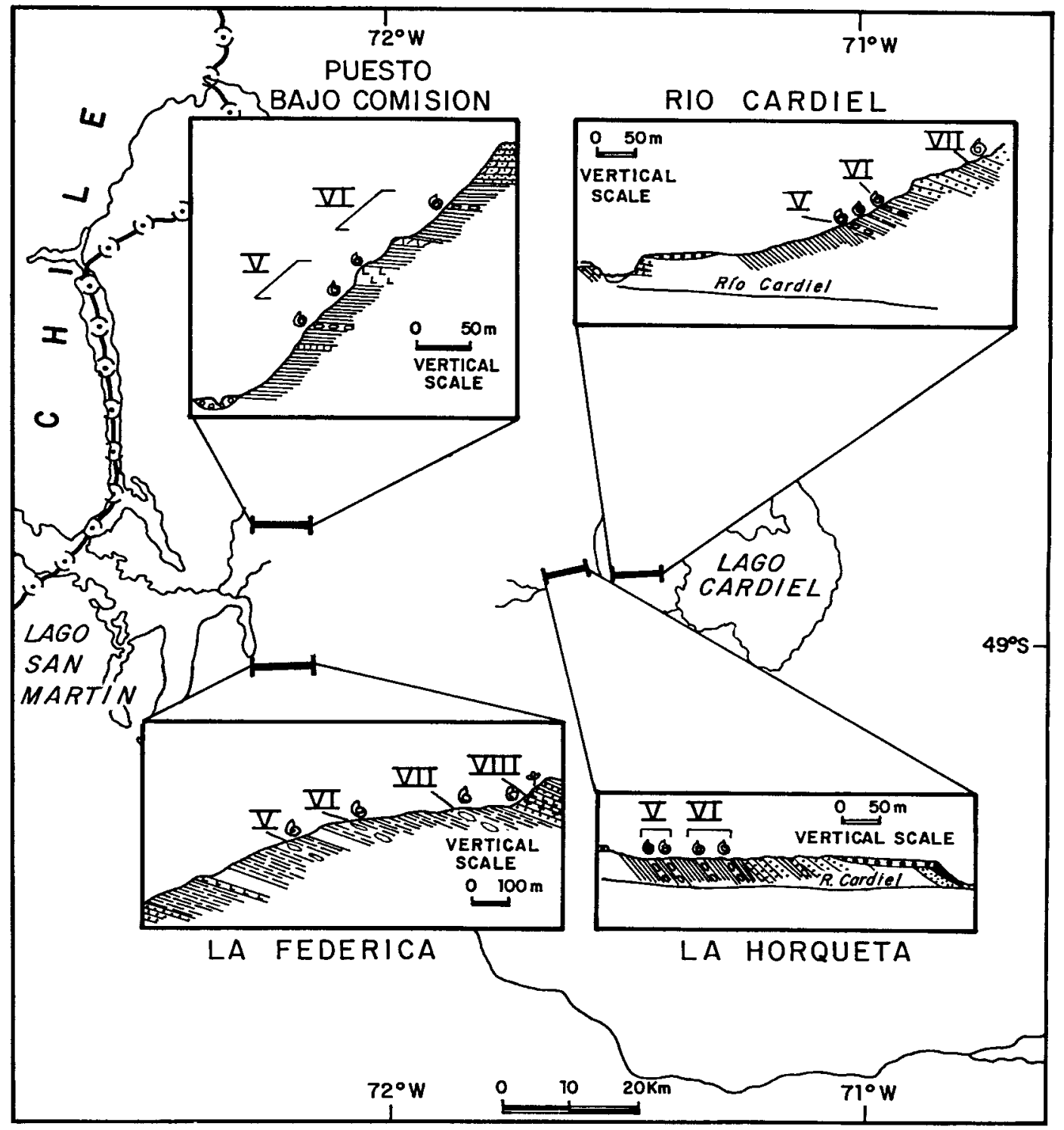




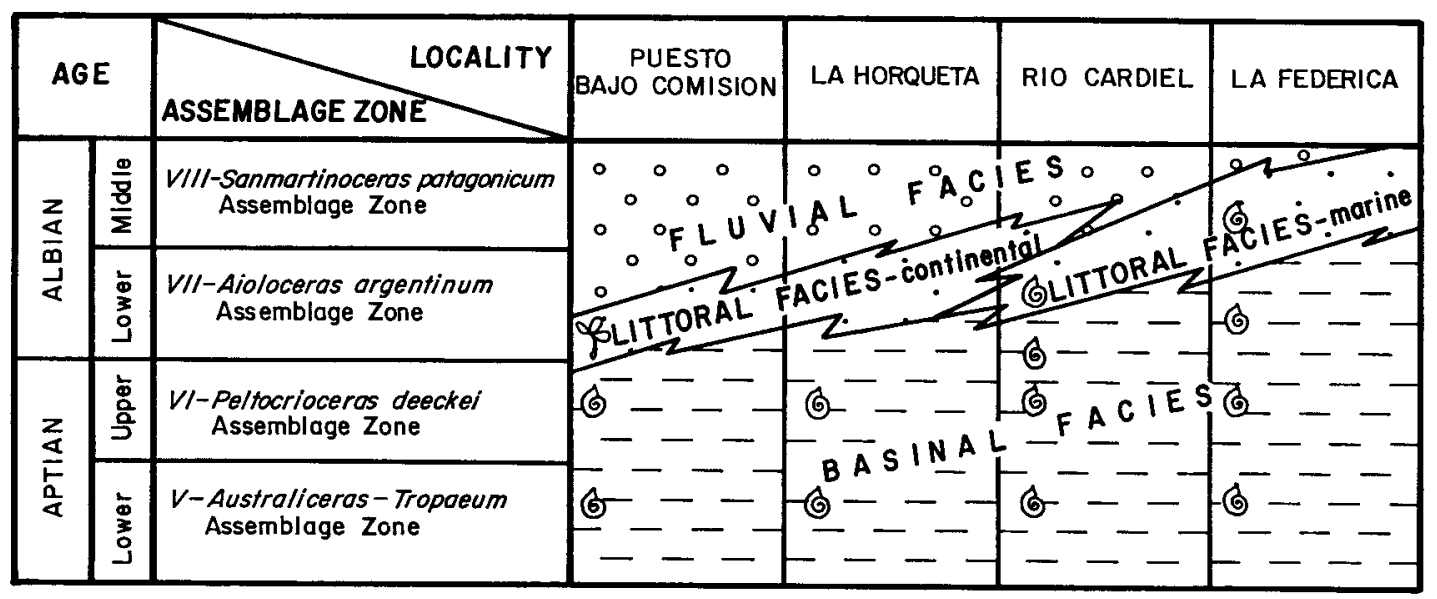

Figure 9.-Biostratigraphic panel showing the corresponding age, assemblage zone, and relation of facies of the Lower Cretaceous sediments from different localities in the west-central part of the Austral basin. These localities are perpendicular to the axis of the basin.

vation of the ammonoid fauna. This probably corresponds to a marked Valanginian low stand, which caused faunal breaks and a stratigraphic hiatus (Riccardi, 1988).

The Austral basin began its development during an extensive marine transgression in the Tithonian (latest Jurassic). The irregular surface of older Jurassic volcanic rocks was covered by continental to marine sandstones of Berriasian to early Valanginian age (Riccardi, 1976, 1977). The maximum advance of the transgressive sea during the Hauterivian (Riccardi, 1987) probably was related to the combination of a global rise in sea level, high subsidence rates, and low clastic input (Aguirre-Urreta and Ramos, 1981). Thick sequences of black shales accumulated in pelagic environments under euxinic conditions. These sedimentary successions were accompanied in the north by shallow marine deposits (see fig. 10A).

The black shales deposited in anoxic and restricted environments precluded the development of benthic faunas, a fact that characterized the Austral basin during most of the Cretaceous. The fossil fauna generally is preserved in calcareous nodules and mostly consists of cephalopods (ammonoids, nautiloids, and belemnoids) of very low diversity (see fig. 4) and a distinctively endemic character. In fact, the two Favrella Assemblage Zones of the Hauterivian are nearly monospecific, as the rest of the faunal components include just a few specimens, even one, among hundreds of specimens of Favrella. It is worth noting here that the accompanying ammonoid fauna, although very limited, shows a mixture of Boreal and Mediterranean elements, a unique phenomenon in the biogeographic patterns of the Austral basin.

Marine sedimentation continued in the Austral basin during the Barremian (see fig. 10B), although a regressive cycle began. The black shales facies were more restricted and were accompanied by the deposition of nearshore and continental deposits in the north. This period was characterized by maximum progradation of littoral facies, but the faunal diversity was still very low. During the early Barremian, the associations were dominated by several species of the ammonite Hatchericeras, together with ancyloceratids and other ammonites that show affinities with fossils from South Africa and Madagascar (Aguirre-Urreta and Ramos, 1989).

In the late Barremian, a marked change took place in the faunal assemblage. All these components were strongly linked, if not identical, with coeval South African faunas (Aguirre-Urreta and Klinger, 1986). It is evident that free marine connections developed between southern Patagonia and southeastern Africa by late Barremian time.
The Aptian shows important paleogeographic changes (fig. 10C). These changes probably were related to a global fall in sea level. together with the beginning of the uplift of the Patagonian Andes (Aguirre-Urreta and Ramos, 1981). The basinal facies represented by euxinic black shales were much more restricted to the south and graded eastward and westward to clastic littoral environments.

The peak of the highest faunal diversity was registered in the Aptian. The early Aptian was dominated by giant ancyloceratids (fig. 11) of strong Indo-Pacific and Mediterranean affinities. In the late Aptian, a giant ancyloceratid was still present, but it was accompanied by several species of aconeceratids and some other species of smaller ancyloceratids. Locally, decapod crustaceans were also common (Aguirre-Urreta, 1989). Open circulation of the South Atlantic Ocean was fully achieved in the Aptian, and the development of these marine connections allowed free faunal migrations from the Mediterranean region through the Caucasus and along the eastern border of Africa to southern Patagonia. It is also possible to compare Patagonian faunas with some Australian faunas.

During the Albian, the basinal facies were limited to a small part of the western area of the central Austral basin (fig. 10D). These deposits grade eastward to conspicuous nearshore deposits containing locally common marine fauna. The volcanic activity continued in the west, while to the east, thick sequences of lacustrine and fluvial sediments were deposited. Abrupt faunal changes were recorded at the beginning of the Albian (Riccardi, 1988, fig. 21). The giant ancyloceratids disappeared, and the lower Albian assemblage zone is dominated by ammonites of more cosmopolitan distribution. The middle Albian was poorly fossiliferous, being characterized by the aconeceratid Sanmartinoceras patagonicum. The late Albian is known only from an isolated outcrop that is situated south of the study area.

\section{Conclusions}

In recent years, our knowledge of the sedimentary and paleobiogeographic history of the Austral basin has improved tremendously as a result of using traditional concepts and "old-fashioned paleontological work." However, we still have a long way to go in applying classic paleontological concepts, not only in incompletely explored distant regions such as the Patagonian cordillera but in many apparently well 


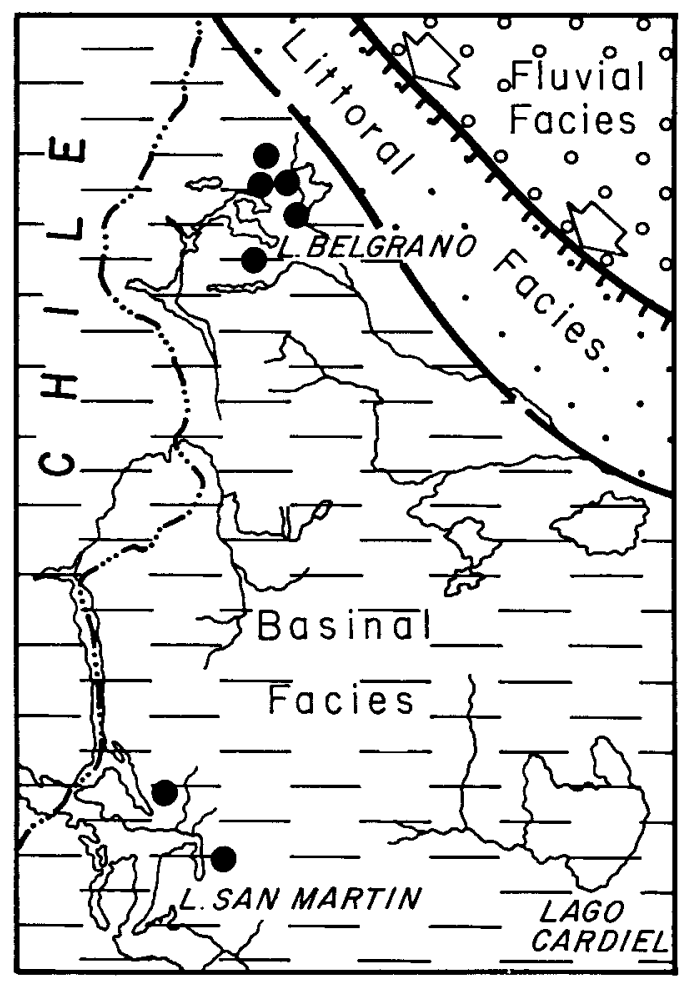

A, HAUTERIVIAN

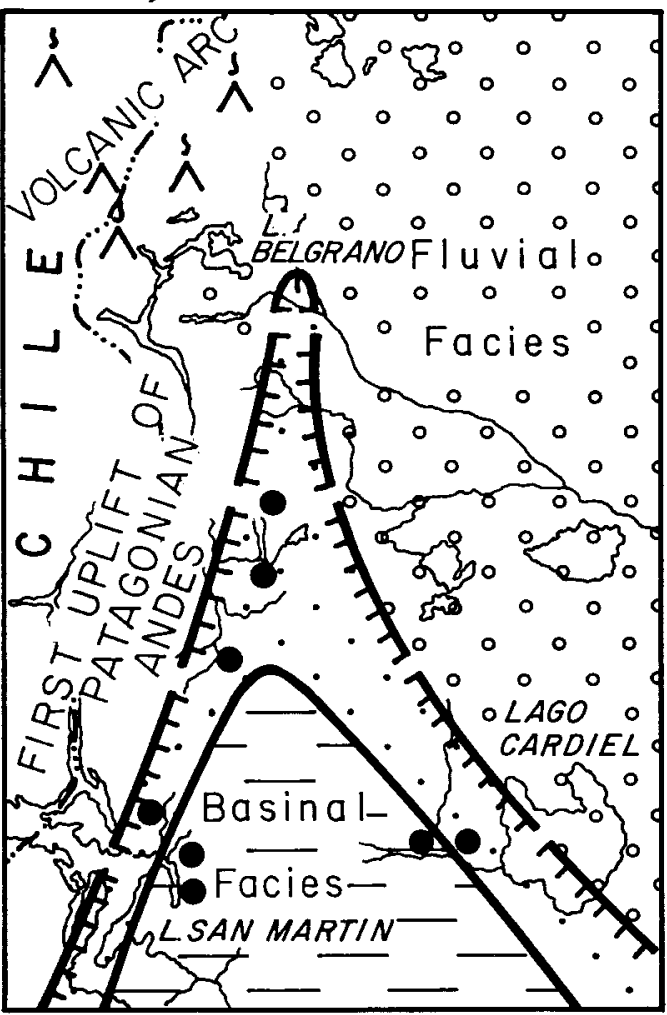

C, APTIAN

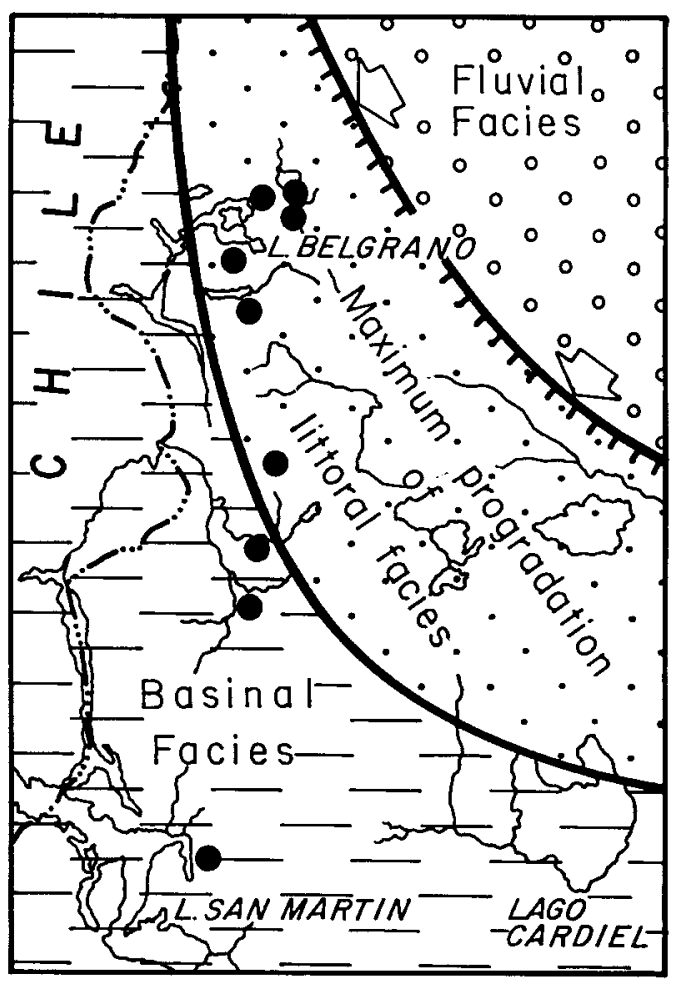

B, BARREMIAN

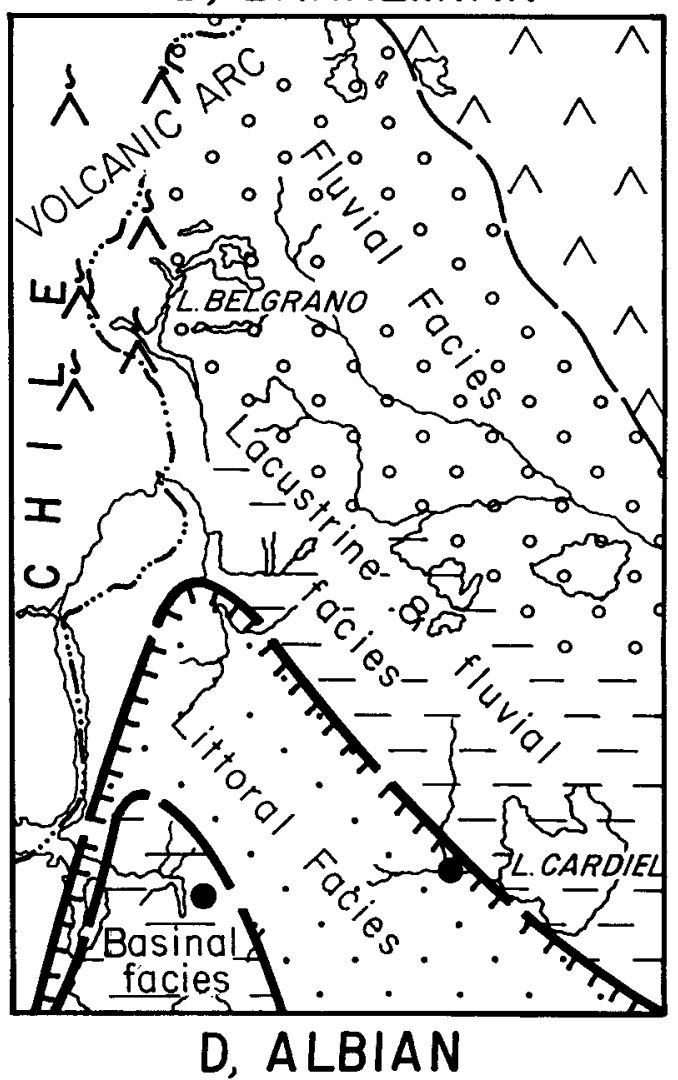

Figure 10.-Four stages of the paleogeographic evolution of the Austral basin during the Early Cretaceous. Black dots indicate points of control. 


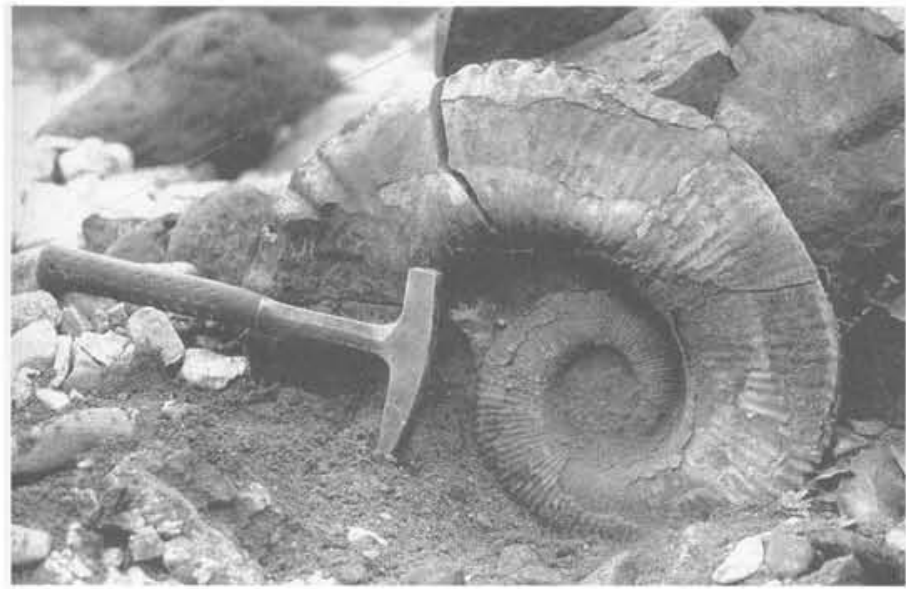

Figure 11.-Tropaeum (Australotropaeum) magnum AguirreUrreta, one of the many giant lower Aptian ancyloceratid ammonoids from the locality of Arroyo La Potranquita.

known areas of Europe and North America. Together these studies will provide an indispensable complement to the attractive world of paleobiology.

\section{Acknowledgments}

I want to thank Dr. A.C. Riccardi and Dr. V.A. Ramos for many years of fruitful discussions. I am also grateful to a number of colleagues for their assistance in numerous field trips to Patagonia.

\section{References}

Aguirre-Urreta, M.B., 1989, The Cretaceous decapod Crustacea of Argentina and the Antarctic Peninsula: Palaeontology, v. 32, no. 3, p. 499-552.

Aguirre-Urreta, M.B., and Klinger, H., 1986, Upper Barremian Heteroceratinae (Cephalopoda: Ammonoidea) from Patagonia and Zululand, with comments on the systematics of the subfamily: South African Museum Annals, v. 96, no. 8, p. 315-358.

Aguirre-Urreta, M.B., and Ramos, V.A., 1981, Estratigrafía y Paleontología de la Alta Cuenca del Río Roble, Cordillera Patagónica, provincia de Santa Cruz: Congreso Geológico Argentino, 8th, San Luis, Argentina, 1981, Actas, v. 3, p. 101-138.

-1989. Subsaynella (Malgasaynella): un amonite barremiano de la zuesta del Oro, Cordillera Patagónica de Santa Cruz, Argentina: Zongreso Argentino de Paleontología y Bioestratigrafía, 4th, Actas, v, 4, ). 55-63.

Birkelund, T., Hancock, J.M., Hart, M.B., Rawson, P.F., Remane, J., Robaszynski, F., Schmid, F., and Surlyk, F., 1984, Cretaceous stage boundaries-Proposals: Geological Society of Denmark Bulletin, v. 33, p. 3-20.

Bonarelli, G., and Nágera, J.J., 1921, Observaciones geológicas en las inmediaciones del lago San Martín (Territorio de Santa Cruz): Dirección General de Minas, Geologia e hidrologia Boletín, v. 27, Argentine Republic, series B, p. 1-39.

Drushchitz, V.V., 1962, O granitse mezhdu gotersivskim barremskim yarusami: Doklady Akademii Nauk SSSR, v. 147, no. 4, p. 900-903 [in Russian],

Kilian, W., 1888, Description géologique de la Montagne de Lure (BassesAlpes): Annales des Sciences Géologiques de Paris, v. 19-20, p. 1-458.
Lapeyre, J.F., and Thomel, G., 1974, Considérations sur la valeur et la situation stratigraphique précise de la zone à Angulicostata (Néocomien): Comptes Rendus de l'Académie des Sciences, série D, v. 278, no. 23, p. 2889-2892.

Macellari, C.E., 1988, Cretaceous paleogeography and depositional cycles of western South America: South American Earth Sciences Journal, v. 1, no. 4 , p. 373-418.

Orbigny, Alcide d', 1840, Céphalopodes, v. 1 of Paléontologie française. Terrains crétacés: Paris, p. 1-662.

Ramos, V.A., 1983, Evolución tectónica y metalogénesis de la Cordillera Patagónica: Congreso Nacional de Geología Económica, 2nd, San Juan, Argentina, 1983, Actas, v. 1, p. 107-124.

1989, Foothills structure in northern Magallanes basin, Argentina: American Association of Petroleum Geologists Bulletin, v. 73, no, 7, p. $887-903$.

Rawson, P.F., 1983, The Valanginian to Aptian Stages-Current definitions and outstanding problems: Zitteliana, v. 10, p. 493-500.

Riccardi, A.C., 1976, Paleontología y edad de la Formación Springhill: Congreso Geológico Chileno, 1st, Santiago, Chile, 1976, Actas, y. 1. p. C41-C56.

-1977 . Berriasian invertebrate fauna from the Springhill Formation of southern Patagonia: Neues Jahrbuch für Geologie und Paläontologie Abhlandulgen, v. 155 , p. 216-252.

1984a, Las Asociaciones de Amonitas del Jurásico y Cretácico de la Argentina: Congreso Geológico Argentino, 9th, San Carlos de Bariloche, Argentina, 1984, Actas, v. 4, p. 559-595.

1984b, Las zonas de Amonitas del Cretácico de la Patagonia (Argentina y Chile): Memorias del Tercer Congreso Latino-americano de Paleontología, v. 1, p. 346-405.

1987, Cretaceous paleogeography of southern South America: Palaeogeography, Palaeoclimatology, Palaeoecology, v. 59, p. 169-195.

-1988, The Cretaceous System of southern South America: Geological Society of America Memoir 168, $161 \mathrm{p}$.

Riccardi, A.C., Aguirre-Urreta, M.B., and Medina, F., 1987 Aconeceratidae (Ammonitina) from the Hauterivian-Albian of southern Patagonia: Palaeontographica, abteilung A, Palaeozoologie Stratigraphie, v. 196, nos. 4-6, p. 105-185.

Riccardi, A.C., and Rolleri, E.O., 1980, Cordillera Patagónica Austral, in Turner, J.C.M., ed., Segundo Simposio de Geología Regional Argentina, 1976: Córdoba, Argentina, Academia Nacional de Ciencias, v. 2. p. 1173-1306.

Russo, A., and Flores, M.A., 1972, Patagonia Austral Extra Andina, in Leanza, A.F., ed., Geología Regional Argentina; Resultados del Primer Simposio de Geología Regional Argentina, 1969: Córdoba, Argentina, Academia Nacional de Ciencias, p. 707-725.

Thomson, M.R.A., 1974, Ammonite faunas of the Lower Cretaceous of southeastern Alexander Island: British Antarctic Survey Scientific Reports, v. 80 , p. $1-44$.

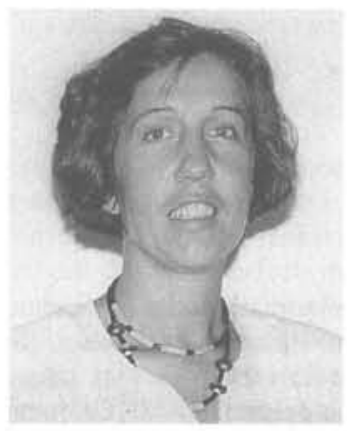

Dr. M.B. Aguirre-Urreta graduated from the University of Buenos Aires in 1978. She is working now at the University of Buenos Aires (Departamento de Ciencias Geoloogicas, Ciudad Universitaria, 1428, Buenos Aires, Argentina) as an Adjunct Researcher for CONICET (National Council for Scientific and Technical Research). She is studying the Cretaceous stratigraphy and ammonoid fauna of the Austral and Neuquén basins of Argentina, and she has also published several papers on Cretaceous belemnites and decapod crustaceans. Dr. Aguirre-Urreta was one of the first three recipients of the IUGS Hutchison Young Scientist Award. 